\title{
LAY USE OF AMAZONIAN PLANTS FOR THE TREATMENT OF TUBERCULOSIS
}

\author{
Christine STOREY ${ }^{1}$, Júlia Ignez SALEM ${ }^{2}$
}

\begin{abstract}
The Brazilian State of Amazonas has a high incidence of Tuberculosis, 91.4 in 10,000 habitants (SESAU, 1994) and resistant strains of Mycobacterium tuberculosis are frequently being found in the region (SALEM et.al, 1990). These problems have been associated with side effects caused by the antibiotics used to treat Tuberculosis, which have in turn been associated with treatment non-compliance (PATTISAPU, 1984). To resolve this problem a cost effective alternative treatment for Tuberculosis with few or no side effects, needs to be found. Amazonas has an abundance of plants, many of which are used by the lay population for medicinal purposes. A survey was carried out in five towns of the region, interviewing patients receiving treatment for Tuberculosis, to find out whether and which plants have been used to treat Tuberculosis. Results showed that the majority of patients in the sample had used medicinal plants before or after diagnosis of Tuberculoses. Thirteen different plants were recorded for this purpose. Chenopodium ambrosioides L., popularly known as Mastruz, was the most commonly used, followed by Caesalpinia ferrea Mart. Juca and Spilanthes acmella D.C. Jambu. This study concentrates on Mastruz as it was used more frequently than the other medicinal plants. No significant effects on baciloscopy test results were found when Mastruz was used before diagnosis. In-vitro laboratory tests have also not shown any tuberculocidal effects for Mastruz. Further tests are being carried out on the other medicinal plants.
\end{abstract}

Key words: Tuberculosis, Amazonas, medicinal plants, lay beliefs.

\section{Conhecimento Popular Sobre o Uso de Plantas da Amazônia no Tratamento de Tuberculose.}

RESUMO - O Estado do Amazonas tem uma alta incidência de tuberculose, 91.4 por 10,000 habitantes (SESAU, 1994), e freqüentemente novas cepas de Mycobacterium tuberculosis resistentes a diversos antibióticos são encontrados (SALEM et.al, 1990). O abandono terapêutico está sendo relacionada aos efeitos colaterais desses antibióticos, contribui para este quadro (PATTISAPU, 1984). Assim faz-se necessário a descoberta de substâncias alternativas com baixo nivel de efeitos colaterais negativos para o tratamento de tuberculose. Neste estado existe abundância de plantas utilizadas pela população no combate a várias doenças. Um levantamento foi feito com portadores de tuberculose emtratamento alopático em cinco municipios do estado do Amazonas, para descobrir quais são as plantas utilizadas por eles. Os resultados mostraram que a maioria dos pacientes entrevistados utilizavam plantas medicinas antes e/ou após tratamento alopático. Treze plantas foram citadas como plantas medicinais e utilizadas no tratamento de tuberculose. Chenopodium ambrosioides L., popularmente conhecida por mastruz, foi relatada como a planta mais utilizada, seguida pela Caesalpinia ferrea Mart., jucá e Spilanthes acmella D.C., jambu. Este estudo se concentra no mastruz por causa da baixa utilização das outras. Não encontramos um efeito significativo no comportamento baciloscópio quando o mastruz foi utilizada antes da diagnóstico. Testes de laboratórios "in-vitro" também não mostraram um resultado tubeculocida para mastruz. Outros testes estão sendo feito com as outras plantas citadas.

Palavras chaves: Tuberculose, Amazonas, plantas medicinais, saber popular.

\section{INTRODUCTION}

Theoretically Tuberculosis is curable, but there are obstacles that often prevent this. These obstacles are in- creasingly present and have a negative circular effect. Treatment for Tuberculosis is a combination of antibiotics taken for a period of at least six months. Multiple intake of antibiotics is

Researcher at the Centre for Studies and Development of Environmental Education - INPA

2 Researcher at the Department of Health Studies - INPA

* INPA, C.P. 478, Manaus, AM, 69011-090, Brazil 
used for, if only one is taken, resistant strains of the bacteria may occur (CANNETI et al., 1972; DAVID, 1980). These antibiotics can react quickly and the overt symptoms of Tuberculosis will soon diminish, they may also cause disagreeable side effects. These two facts have been related with treatment non-compliance (PATTISAPU, 1984). The side effects cause the patient to stop treatment or the antibiotics induce relief for the patient, which creates a false notion of cure, so there is no apparent need to continue treatment. However, the bacillus, Mycobacterium tuberculosis is still present in the body, this dormant bacillus now may be resistant to the antibiotics used in the first course of treatment. Therefore, non-compliance is considered as a causal factor for the occurrence of drug resistant strains of Mycobacterium

tuberculosis (THOMAN, 1986; GANGADHARAM, 1984). During the past two decades these drug resistant strains have been recorded as increasing (CANNETI et al., 1972; DAVID, 1980; THOMAN, 1986). The frequency of resistance recorded for Isoniazide, Rifampicine and Pirazinamide (scheme 1 for the treatment of Tuberculosis), were $18.4 \%, 6.9 \%$ and $1.1 \%$ respectively, in the State of Amazonas (SALEM et al., 1990). This making medical care for tuberculosis more difficult, complicated and expensive.

A preliminary survey carried out in the Micobacteriology Laboratory at the National Institute for Research in Amazonas (INPA, personal information), recorded seventeen different medicinal plants in lay use by patients receiving treatment for Tuberculosis, in Manaus. The most commonly used was Chenopodium ambrosioides L., popularly known as Mastruz. Observations indicated that this plant reacted against the bacillus $M . t u$ berculosis, as the patients who had reported using the plant before diagnosis had low or negative baciloscopy results (the presence of alcohol-acid resistant bacillus - BAAR, from lung secretions). Forming the hypothesis that Mastruz has a tuberculocidal effect, but it had been taken in insufficient doses to have a total effect.

There are many Amazonian medicinal plants that are used by the lay population to cure various diseases, (MONTEIRO, 1988; THOMAN, 1986; VAN DEN BERG \& LIMA DA SILVA, 1986). Branch and Silver (BRANCH \& SILVA, 1983), alert us to the fact that it is important to study these plants. In order that information on them can be documented before it disappears with modernisation, urbanisation and influx of people from other regions to Amazonas. In order to confirm whether and which medicinal plants are used to cure Tuberculosis, a survey of patients receiving treatment for Tuberculosis was carried out in five towns of the region. After data collection the plants were laboratory tested for tuberculocidal activities.

\section{Methodology}

The research tool used for the survey was a questionnaire with open and closed questions. A pilot study was carried out to validate the questions, then discussed with a multidiciplinary team. The questions covered: identification; social status; occurrence of Tuberculosis; clinical profile; medicinal plants used; methods 
of preparation; dosage; who influenced use, if they had used them and if so from where they had been obtained.

In order to achieve good coverage of the region, five towns along three rivers were chosen: Manaus (the State capital) and São Gabriel da Cachoeira, on the River Negro; Manacapuru and Tefé, on the River Solimões and Itacoatiara on the River Amazonas.

The population studied was patients receiving treatment for Tuberculosis. In Manaus about 1100 cases of Tuberculosis are treated per year (SESAU, 1994). A sample of 200 patients receiving treatment at the Regional Centre of Specialisation in Sanitary Pneumology "Cardoso Fontes", were interviewed. In other towns the intention was to interview all patients receiving treatment at state health centres, where Tuberculosis is treated. However, this was not possible, due to the distance and location of some residences, only accessible by river. A scale asking questions about house-hold and electrical goods etc., was used to obtain information on social status. This was adapted from scale used by SOARES \& FERNANDES (1989), to comply with regional culture.

After interviews were completed, samples of the three most frequently cited plants were purchased from the Municipal market in Manaus, this being the market most frequently mentioned by interviewees. Botanical identification was then carried out by comparing specimens with those in the Herbarium at INPA's Botanical Department. This task was carried out by the Department's technical staff.

The data obtained from the questionnaires were processed using Microsoft Access Database. The data were then analysed using Chi-squared test, Fisher's exact test and Friedman's probability (KIRKWOOD, 1991).

\section{RESULTS}

Geographical details of the Towns are in Table 1. The use of medicinal plants was recorded in all of the towns, except for São Gabriel da Cachoeira. In three towns medicinal plants were taken by more than $55 \%$ of the interviewed patients and in Tefé by $33 \%$ of the patients (Tab. 2). The most common plant used was Chenopodium ambrosioides L., popularly known as Mastruz, followed by Spilanthes acmella D.C. Jambu and Caesalpinia ferrea Mart., Jucá (Tab. 2). Others were used infrequently or together with the first plant cited (Tab. 3).

The Chi-squared test was used to

Table 1. Geographical details of the five towns studied. Information obtained from the 1992 census (IBGE, 1992).

\begin{tabular}{|c|c|c|c|c|}
\hline Towns & Location & River & Inhabitants & Density $h a b / k^{2}$ \\
\hline Manaus & & Negro & $1,010,544$ & 92,19 \\
\hline Sâo Gabriel & $852 \mathrm{Km}$ NW from Manaus & Negro & 23,144 & 0,21 \\
\hline Manacapuru & $80 \mathrm{Km} \mathrm{S}$ from Manaus & Solimões & 57,123 & 7,93 \\
\hline Tefé & $700 \mathrm{Km} \mathrm{W}$ from Manaus & Solimões & 54,045 & 2,28 \\
\hline Itacoatiara & $280 \mathrm{Km}$ E from Manaus & Amazon & 59,096 & 9,45 \\
\hline
\end{tabular}


Table 2. Number of patients registered as receiving treatment for Tuberculosis at the time of our survey $(\mathrm{R})$, number of patients interviewed $(\mathrm{N})$, percentage of patients who used medicinal plants before or after diagnosis $(\mathrm{P})$ and the medicinal plants most frequently used in five towns of the State of Amazonas:

\begin{tabular}{lcccccccc}
\hline Towns & & & & & \multicolumn{4}{c}{ Medicinal Plants } \\
\hline Manaus & $\mathrm{R}$ & $\mathrm{N}$ & $\mathrm{P}$ & $\mathrm{Am}^{1}$ & $\mathrm{Ca}^{2}$ & $\mathrm{Ju}^{3}$ & $\mathrm{Ja}^{4}$ & $\mathrm{Ma}^{5}$ \\
\hline São Gabriel & 30 & 200 & $55.5 \%$ & $1 \%$ & $1 \%$ & $2.8 \%$ & $1 \%$ & $94.5 \%$ \\
Manacapuru & 20 & 9 & $55.5 \%$ & $0 \%$ & $0 \%$ & $40 \%$ & $20 \%$ & $40 \%$ \\
Tefé & 22 & 15 & $33.3 \%$ & $0 \%$ & $0 \%$ & $20 \%$ & $20 \%$ & $60 \%$ \\
Itacoatiara & 27 & 14 & $71,4 \%$ & $0 \%$ & $0 \%$ & $10 \%$ & $10 \%$ & $80 \%$ \\
\hline
\end{tabular}

1. Am - Amapá - Parahancornia amapa L.

2. Ca - Carapanauba - Aspidosperma carapanauba Pichon;

3. Ju - Jucá - Caesalpinia ferrea Mart.

4. Ja - Jambu - Spilanthes acemella D.C.

5. Ma - Mastruz - Chenopodium ambrosiodes L.

Table 3. Plants cited as being taken in conjunction with plants in Table II:

\begin{tabular}{lc}
\hline \multicolumn{1}{c}{ Medicinal Plant } & Frequency of use \\
\hline Sucupira Bowdichia virgilioides H.B.K. & 1 \\
Andiroba Carapa guianensis Aubl. & 2 \\
Saracuramirá Ampelozizyphus amazonicus Ducke. & 1 \\
Malvarisco Potomorphe peltata (L.) Miq. & 1 \\
Saião Kalanchloe brasiliensis Camb. & 1 \\
Jambu Spilanthes acmella D.C. & 5 \\
Crajiru Arrabidaea chica (H.B.K.) Verlot. & 2 \\
Mangarataia Zingiber officinale Rosc. & 1 \\
Juca Caesalpinia ferrea Mart. & 14 \\
Carapanaúba Aspidosperma carapanauba Pichon. & 1 \\
Jatobá Hymenaea courbaril L. & 1 \\
\hline
\end{tabular}

analyse differences in the use of medicinal plants between males and females, in Manaus. Fisher's exact test was used for the other towns, due to the small sample size. No significant differences $(\mathrm{P}<0.05)$ were found between sexes in any of the towns (Tab. 4). The Chisquared test was also used to analyse differences between social status and the use of medicinal plants. No significant differences were found between social status in any of the towns (Tab. 5).
The majority of the patients who used medicinal plants seemed to be influenced by family or friends. Those who gave information, had in most cases previously used it themselves (Tab.6). The cultivation of the plants in gardens or private areas, was cited more often in Tefé than the other towns, where they were more commonly purchased from markets.

Mastruz had no clear effect on the baciloscopy test results (Tab. 7). De- 
Table 4. Use of medicinal plants by males and females: 1 = probability of the Chi-squared test; $2=$ probability of Fisher's exact test, ns $=$ no significant difference.

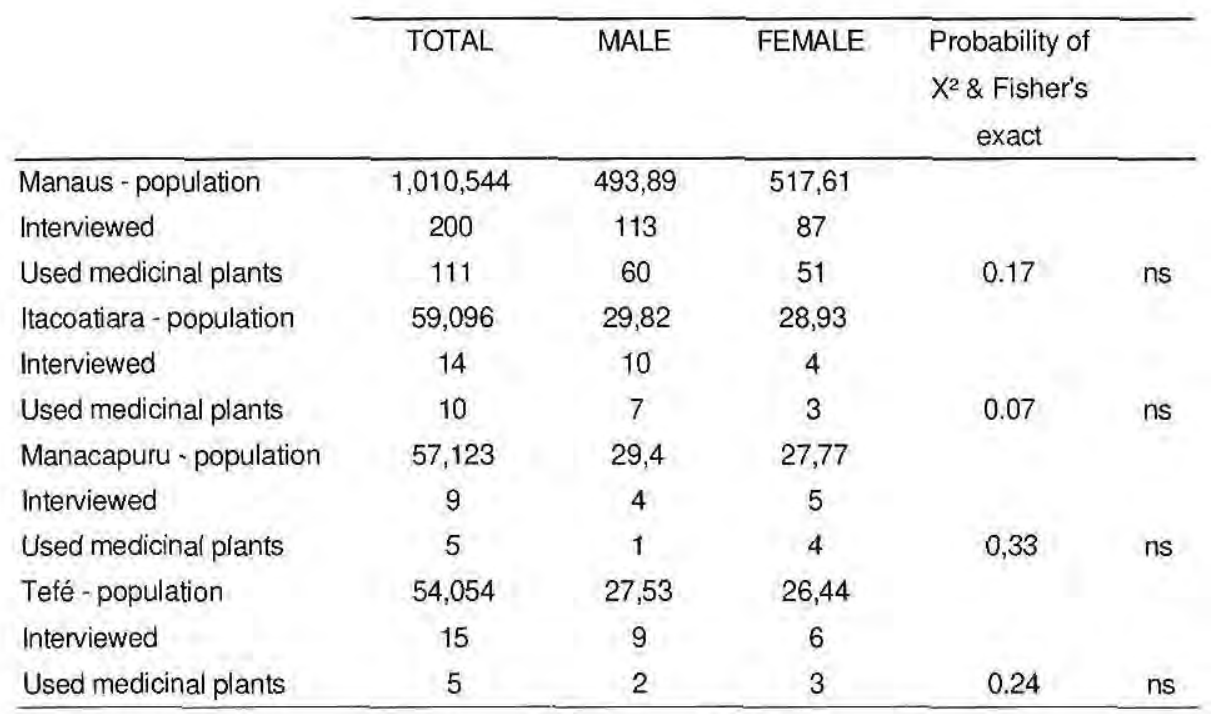

Table 5. Use of medicinal plants between social status, ns = no significant difference.

\begin{tabular}{lccccc}
\cline { 2 - 5 } & Lower & Lower-middle & Middle & $\begin{array}{c}\mathrm{X}^{2} \text { estimated } \\
\text { probability }\end{array}$ & \\
\hline Manaus - total & 80 & 114 & 6 & & \\
Used medicinal plants & 40 & 69 & 2 & & \\
Did not use & 40 & 45 & 4 & & $\mathrm{~ns}$ \\
Itacoatiara - total & 9 & 5 & 0 & & \\
Used medicinal plants & 5 & 5 & 0 & & $\mathrm{~ns}$ \\
Did not use & 4 & 0 & 0 & & \\
Manacapuru - total & 5 & 4 & 0 & & \\
Used medicinal plants & 3 & 2 & 0 & & \\
Did not use & 2 & 2 & 0 & & \\
Tefé - total & 11 & 4 & 0 & & \\
Used medicinal plants & 5 & 0 & 0 & & \\
Did not use & 6 & 4 & 0 & 1.66 & $\mathrm{~ns}$ \\
\hline TOTAL & 113 & 128 & 6 & & \\
\hline
\end{tabular}


Table 6. Sources of influence for the use of medicinal plants and if they had used them as well.

\begin{tabular}{llll} 
FAMILY FRIEND & $\begin{array}{c}\text { HEALTH } \\
\text { WORKER }\end{array}$ & OTHER & TOTAL \\
\hline
\end{tabular}

\begin{tabular}{lccccc}
\hline Manaus & 73 & 34 & 1 & 3 & 97 \\
Used as well & 66 & 30 & 1 & 0 & 9 \\
Itacoatiara & 7 & 0 & 3 & 0 & \\
Used as well & 6 & 0 & 3 & 0 & 3 \\
Manacapuru & 1 & 3 & 1 & 0 & 2 \\
Used as well & 1 & 2 & 0 & 0 & 111 \\
Tefé & 3 & 0 & 2 & 0 & \\
Used as well & 2 & 0 & 0 & 0 & 1 \\
\hline TOTAL & 84 & 37 & 7 & 1 & \\
\hline
\end{tabular}

Table 7. Daily dosage and baciloscopy test results of patients interviewed in Manaus. All patients had taken Mastruz before diagnosis.

\begin{tabular}{lcccc}
\hline Test results & \multicolumn{3}{c}{ Daily Dosage } & Total \\
\hline BacDir + & $150 \mathrm{ml}$ & $300 \mathrm{ml}$ & $500 \mathrm{ml}$ \\
BacDir ++ & 3 & 6 & 3 & 12 \\
BacDir +++ & 4 & 2 & 3 & 9 \\
BacNegRXalt & 8 & 8 & 3 & 19 \\
Clinical symptoms & 6 & 4 & 3 & 13 \\
Cultive-BK & 2 & - & - & 2 \\
\hline Total & 1 & - & - & 1 \\
\hline
\end{tabular}

spite a slight reduction in the number of positive results with an increase in the dosage, these differences were not statistically significant (Friedman's test, $\mathrm{N}=$ $12, \mathrm{P}=0.22$ ).

\section{DISCUSSION}

The purpose of this study was to find out whether and which medicinal plants are used by the lay population to treat Tuberculosis. Then laboratory test the plants for Tuberculocidal activities.

In all of the towns except São Gabriel da Cachoeira, it was possible to state that the majority of the patients interviewed used medicinal plants (Tab.2). The population of São Gabriel da Cachoeira is comprised of more indigenous groups, than the other towns surveyed. This could be why the use of medicinal plants was not recorded. For indigenous populations Tuberculosis is an illness of the "Branco" (white people), therefore, it can only be treated by white people, indigenous lay beliefs have not formulated a treatment for this disease.

Methods of preparation and doses taken of the medicinal plants (Tab. 8), were similar in the different towns. This suggests that there is a code traditional knowledge in the region, which is passed verbally from generation to generation. Inversely 
Table 8. Preparation of the three principal medicinal plants used.

\begin{tabular}{llllll}
\hline Plant & Part of plant & State & \multicolumn{1}{c}{ Dilution } & \multicolumn{1}{c}{ Preparation } & Daily dosage \\
\hline Mastruz & leaf & fresh & 1 bunch $500 \mathrm{ml}$ water & juice/condenced milk & $200 \mathrm{ml}$ \\
Jucá & pod & dry & 2 pods 1 lit weter & infusion & ad libetum \\
Jucá & pod & dry & 2 pods 1 lit water & tea & ad libetum \\
Jambu & leaf \& flower & fresh & hand full $500 \mathrm{ml}$ water & juice $/$ condensed milk & ad libetum \\
Jambu & leaf \& flower & fresh & hand full $500 \mathrm{ml}$ water & tea & $200 / 400 \mathrm{ml}$ \\
\hline
\end{tabular}

SHULTS \& RAFFAUF (1990), in their study on medicinal plants used by Amazonian indigenous populations, found a disparity in the plants used between tribes. An explanation for this could be that the caboclo (mixture of European, African and indigenous populations) traditions have developed as a mixture of knowledge from indigenous populations, African immigrants from the Northeast and European colonisers. The source of this knowledge and the influence of the latter, that superseded the indigenous, is an area that needs to be further studied.

The majority of the patients diagnosed as having Tuberculosis in the study, were from lower and lower middle social status families. This could be due to the fact that middle and upper income families do not use the state health service or that these income groups suffer less from Tuberculosis.

Results showed that Mastruz was used most frequently to treat Tuberculosis. PABLO (1981), also cites its use as a tuberculocidal. However, our data analysis did not show any significant effect. Although, evidence about the curative value of Mastruz was impeded as interviews were carried out with patients receiving treatment for tuberculosis. Curative values need to be obtained by laboratory tests. These are being carried out in the
Micobacteriology Laboratory at the Department of Health Research, INPA.

It could be that its use in the treatment of Tuberculosis stems from having curable properties for the symptoms of Tuberculosis. For example information obtained during interviews indicated Mastruz as a fortifier, expectorant etc. This is a subject that needs to be tested in-vitro. In conclusion, the hypothesis that Mastruz has a tuberculocidal effect, but has been taken in insufficient doses to have a total effect, is refuted. However, mastruz infusions have proved to be active in treatment against intestinal parasites (ABREU, 1994).

\section{ACKNOWLEDGEMENTS}

We thank, the Secretary of Health for the State of Amazonas (SESAU) - Regional Centre of Specialisation in Sanitary Pneumology "Cardoso Fontes", Foundation SESP and the National Health Foundation's health centres in Manacapuru; Itacoatiara; Tefé and the São Gabriel da Cachoeira Hospital, for their assistance in data collection. We also thank, the staff of INPA's Botanical Department's herbarium for their plant identifications. Dr. Maria das Graças Bichara Zoghbi, professors Maria Inês Gasparetto Higuchi and Aya Sadahiko UFA, for their technical advice and $\mathrm{CNPq}$ for providing the RHAE grant and financial assistance for this study. 


\section{Literature Cited}

ABREU, FJ. 1994. Farmacias Vivas, 20 edição. Fortaleza, EUFC. 179 p.

BRANCH, L.C.; SILVA, M.F. 1983. Folk Medicine of Alter do Chão, Pará, Brazil. Acta Amazonica, 13 (5/6) : 737-797.

CANNETI, G.; GAY, Ph.; LE LIRZIN, M. 1972. Trends in the prevalence of primary drug resistance in pulmonary tuberculosis in France from 1962 to 1970 : A national survey. Tubercle $53: 57-83$.

DAVID, H.L, 1980. Drug resistance in $M . t u-$ berculosis and other mycobacterium. Clinics Chest Med., 1 :227-230.

GANGADHARAM, P.R.J. 1984. Drug resistance in mycobacterium. Florida, CRC Press. $167 \mathrm{p}$.

IBGE, Fundação Instituto Brasileiro de Geografia e Estatistica.1992. Anuário Estatistico do Brasil. Rio de Janeiro, IBGE. 1119 p.

KIRKWOOD, B.R. 1991. Essentials of Medical Statistics. London, Blackwell Scientific Publications. 233 p.

MONTEIRO, M.Y. 1988. Plantas Medicinais e suas virtudes. Acta Amazonica, 18 (1/2) :357-366.

PABLO, C.I.D. 1981. Plantas Medicinais e Ervas Feiticeiras da Amazônia. São Paulo, Atlantis Livros LTD, 194 p.
PATTISAPU, R.J.G.H.1984. Drug Resistance in Mycobacteria. CRC Press Inc, Florida. 150 p.

SALEM, J.I.; GOH, K.S.; LITAIFF, L.R.L.; CARDOSO, M.S.L.; BRIGLIA, M.F.S. 1990. An investigation of primary and acquired Drug-Resistance of M.tuberculosis in Manaus (Amazonas-Brasil). Jornal de Pneumologia, 16 (1) : 6-8.

SCHULTS, R.E.; RAFFAUF, R.F. 1990 . The Healing Forest, Medicinal and Toxic Plants of the Northwest Amazonia. Oregon, Dioscordes Press, 484 p.

SESAU, Secretaria da Saúde do Estado Amazonas, 1994. Relatório: Avaliação das Atividades do Ano 1994 pelo Programa de Controle de Tuberculose. Manaus, Am, SESAU. 30 p.

SOARES, N.E.; FERNANDES, L.M, 1989. A medida do nivel sócio-econômicocultura. Interamerica Journal of Psycology, 41 (2) : 35-45.

THOMAN, K. 1986, Diagnóstico e tratamento da Tuberculose. Organização Mundial de Saúde, União Internacional Contra a Tuberculose. 229-234.

VAN DEN BERG, M.E.; LIMA DA SILVA, M.H. 1986. Plantas Medicinais do Amazonas. DDT, Brasilia. 127p. 